Ambiente \& Água - An Interdisciplinary Journal of Applied Science
ISSN 1980-993X - doi:10.4136/1980-993X
www.ambi-agua.net
E-mail: ambi-agua@agro.unitau.br

\title{
Association between maternal exposure to particulate matter and premature birth
}

\author{
doi: 10.4136/ambi-agua.1262
}

Received: 19 Dec. 2013; Accepted: 08 Mar. 2014

\section{Thaiza Agostini Córdoba de Lima; Luiz Fernando Costa Nascimento*; Andréa Paula Peneluppi de Medeiros; Veridiana de Paula Santos}

\author{
Universidade de Taubaté - Taubaté, SP, Brasil \\ Departamento de Medicina \\ *Autor correspondente: e-mail: luiz.nascimento@unitau.com.br, \\ thaiza_lima2@hotmail.com, apeneluppi@uol.com.br, \\ vevedepaula@hotmail.com
}

\begin{abstract}
The objective of this time-series study carried out in São José dos Campos, a southeastern Brazilian city, between 01.01.2005 and 31.12.2009, was to estimate the role of maternal exposure to air pollutants and preterm births. Preterm newborns of mothers aged between 18 and 34 years, with at least eight years of schooling, singleton pregnancies and whose delivery was vaginal were included in the study. Logistic regression was used to estimate the role of particulate matter, ozone and sulfur dioxide on preterm delivery with lags of zero up to 30 days. Exposure to particulate matter was associated significantly with preterm newborns in lags of 0,1 and 3 days; but no association was found between cumulative maternal exposure in lags of 7, 15 and 30 days and the outcome. Maternal exposure to particulate matter therefore has an acute effect on preterm births in a medium-sized Brazilian town.
\end{abstract}

Keywords: air pollutants, preterm birth, logistic regression, particulate matter, air pollution.

\section{Associação entre a exposição materna ao material particulado e parto prematuro}

\section{RESUMO}

O objetivo deste estudo de séries temporais desenvolvido em São José dos Campos, localizada sudeste do Brasil, entre 01.01.2005 e 31.12.2009, foi estimar o papel da exposição materna aos poluentes do ar e partos prematuros. Recém-nascidos prematuros de mães com idade entre 18 e 34 anos, com pelo menos oito anos de escolaridade, gestações únicas e cujo parto foi vaginal foram incluídos no estudo. A regressão logística foi utilizada para estimar o papel da exposição ao material particulado, ozônio e dióxido de enxofre em trabalho de parto prematuro com defasagens de zero até 30 dias. Exposição ao material particulado esteve associada significativamente com partos prematuros em lag 0,1 e 3 , mas não houve associação entre a exposição materna acumulada sete, 15 e 30 dias antes do parto e o desfecho. Assim, a exposição materna ao material particulado tem um efeito agudo em recém-nascidos prematuros em uma cidade de brasileira de porte médio.

Palavras-chave: poluentes do ar, parto prematuro, regressão logística, material particulado, poluição do ar. 


\section{INTRODUCTION}

Preterm is, according to the International Classification of Diseases (WHO, 1993), a birth that occurs at less than 37 weeks gestational age and is a serious problem for women during pregnancy. These infants have a high risk of illness and death due to their incomplete fetal development and increased susceptibility to infections (Vaast et al., 2004). The etiology of preterm birth is complex and involves several factors including environmental factors. (Nascimento, 2001; Tucker and McGuire, 2005).

Data from the Brazilian Ministry of Health show that the occurrence of preterm births in Brazil grew 27\% between 1997 and 2006, representing an increase of 5.3 to $6.7 \%$ of total births in the country. However, it is not only in Brazil that the table of prematurity increase is showing gradual increases, but also in almost all countries of the world, where some experts believe that an epidemiological perinatal transition is occurring (Silveira et al., 2008).

The main air pollutants are particulate matter $\left(\mathrm{PM}_{10}\right)$, ozone $\left(\mathrm{O}_{3}\right)$ and sulfur dioxide $\left(\mathrm{SO}_{2}\right)$. Particulate material is a mixture of liquid and solid particles suspended in the air, which vary in size (most studied are the particles smaller than 10 microns in aerodynamic diameter - $\mathrm{PM}_{10}$ ) and are emitted via mechanical dispersions of organic material and via uncontrolled combustion. Ozone, a gaseous material with high oxidative and cytotoxic potential, is a secondary pollutant; and sulfur dioxide, also gaseous, is the result of combustion of fossil elements (coal and oil) (Bascom et al., 1996).

Association between maternal exposure to air pollutants and preterm delivery has been demonstrated in several articles (Zhao et al., 2011; Sagiv et al., 2005; Xu et al., 1995; Bobak, 2000; Ritz et al., 2000; Ritz et al., 2007; Leem et al., 2006; Sram et al., 2005; Lacasana et al., 2005; Wilhelm and Ritz, 2005; Huynh et al., 2006; Bell at al., 2007; Steb et al., 2012). These studies have implicated $\mathrm{PM}_{10}, \mathrm{SO}_{2}$, total suspended particles (TSP), $\mathrm{NO}_{2}, \mathrm{O}_{3}$ and $\mathrm{CO}$, especially when analyzed at the beginning or end of pregnancy, in quarters, or even a few days before delivery. A recent review shows studies with associations of exposures to these pollutants and preterm birth and also low birth weight, especially to particulate matter (Kannan et al., 2007).

Given the prevalence of preterm birth in Brazil (approximately 7.0\%) and in the state of São Paulo (about 8.5\%) (Brazil, 2012) and given that the newborn preterm contributed to just over $40 \%$ of deaths in children under 1 year of age in Brazil and to about $44 \%$ of deaths in the state of São Paulo (Brazil, 2012), the aim of this study was to estimate the role of maternal exposure to particulate matter and preterm delivery in São José dos Campos, SP.

\section{MATERIAL AND METHODS}

This is a time-series ecological study on the exposure of pregnant women to air pollutants and preterm births that are consolidated in the Brazilian Information System on Live Births Ministry of Health (SINASC). SINASC was the source of the records.

The study period was from January 1, 2005 to December 31, 2009. The study was conducted in the municipality of São José dos Campos, a city in southeastern Brazil; it is considered medium-sized, and its geographical coordinates are $23^{\circ} 10^{\prime} \mathrm{S}$ and $45^{\circ} 52^{\prime} \mathrm{W}$, being located $600 \mathrm{~m}$ above the sea with tropical humid climate. It has an important industrial park and had an estimated population of just over 600,000 inhabitants in 2009.It is located between São Paulo and Rio de Janeiro, the two largest cities in Brazil, and is crossed by Dutra Highway that carries heavy bus and truck traffic, with a daily flow of approximately 130,000 vehicles.

This database was analyzed in two ways: unadjusted analysis: all preterm infants, without any selection or exclusion criteria; and adjusted analysis, with only those premature 
births by mothers between 18 and 34 years old, resulting from a single pregnancy, whose delivery was vaginal and whose mothers had at least eight years of schooling in order to minimize the effects of these potential confounders. This approach was used in another study (Nascimento and Moreira, 2009).

The Live Birth Certificate (DNV) is an official document required for the civil registration of a child; it contains various information regarding the mother and newborn. We excluded information on premature birth where weight was greater than 2800 grams under the assumption that there was an error or in the evaluation of weight or in the gestational age. Gestational age is categorized into classes: from 22 to 27 weeks of gestation, from 28 to 32 weeks of gestation and from 33 to 36 weeks of gestation.

We selected the data of the concentrations of pollutants: particulate matter under 10 micra in aerodynamic diameter $\left(\mathrm{PM}_{10}\right)$, sulfur dioxide $\left(\mathrm{SO}_{2}\right)$, in its daily means, and ozone $\left(\mathrm{O}_{3}\right)$ in its daily 8-hour maximum, as obtained from Agency of Environmental Sanitation Technology (Cetesb), which has a metering station in São José dos Campos. The Beta monitor technique was used to evaluate the $\mathrm{PM}_{10}$; the coulometry technique was used to evaluate $\mathrm{SO}_{2}$; and chemiluminescence was used for $\mathrm{O}_{3}$. Air pollutants were quantified in $\mu \mathrm{g} \mathrm{m}^{-3}$. Ozone, $\mathrm{PM}_{10}$ and $\mathrm{SO}_{2}$ were analyzed separately (unipollutant model) and jointly (multipollutant model) and their concentrations were analyzed continuously.

We made a 0 to 7 day lag model to study the effects of exposure to air pollutants, because may be a lag for the effects of maternal exposure to pollutants and the outcome. The role of cumulative effects of maternal exposure and preterm birth was analyzed considering lags of seven, 15 and 30 days between exposure and birth.

We used the logistic regression model to estimate the risk for the occurrence of at least one preterm delivery because of maternal exposure to air pollutants. The coefficients obtained through logistic regression can be used to calculate the chances of preterm birth as well as the percentage increase with $20 \mu \mathrm{g} \mathrm{m}^{-3}$ in $\mathrm{PM}_{10}$ concentration increase. We presented in tabular form the values of OR with confidence intervals of $95 \%$ for each pollutant in the multipollutant model and adjusted analysis, with 0-7 day lags and also for the cumulative effects at seven, 15 and 30 days. For unipollutant models, both in the unadjusted and in the adjusted approach, and for the multipollutant model according to the crude analysis, the significant values found $(\mathrm{p}<0.05)$ were reported in the results section.

The software used for this analysis was the SPSS v17.

\section{RESULTS}

Forty-four thousand nine hundred ninety-four children were born during the study period (2005-2009) and 3799 newborn (8.4\%) were preterm births; 769 infants $(20.2 \%$ of all preterm births) met the inclusion criteria. The descriptive analysis with the mean values, minimum, maximum and standard deviation of the pollutants are shown in Table 1.

Table1. Descriptive analysis of air pollutants $\mathrm{SO}_{2}, \mathrm{PM}_{10}$ e $\mathrm{O}_{3}$, São José dos Campos, Brazil, 2005 to 2009.

\begin{tabular}{c|ccc}
\hline POLLUTANT & MEAN (SD) & Min $\left(\boldsymbol{\mu} \mathbf{g ~ m}^{-\mathbf{3}}\right)$ & Max $\left(\boldsymbol{\mu} \mathbf{g ~ m}^{-\mathbf{3}}\right)$ \\
\hline $\mathrm{SO}_{2}$ & $3.16(1.97)$ & 1 & 17 \\
$\mathrm{PM}_{10}$ & $23.93(12.21)$ & 6 & 100 \\
$0_{3}$ & $80.28(32.29)$ & 5 & 209 \\
\hline
\end{tabular}

SD: standard deviation; Min: minimum values; Max (maximum values). 
The distribution of concentrations of pollutants over the period identified that ozone did not show a seasonal behavior, unlike $\mathrm{SO}_{2}$ and $\mathrm{PM}_{10}$, whose highest concentrations occurred in the winter months. The distribution of preterm births by month of birth appears to show a seasonal pattern, with higher values in July and August, months with higher concentrations of pollutants (data not shown). However, this distribution does not seem to repeat seasonally, when only the cases that met the inclusion criteria were inserted.

\subsection{Statistical results}

\subsubsection{Unipollutant model}

The coefficients obtained from the logistic regression, analyzing maternal exposure to $\mathrm{PM}_{10}$, showed a significant result in the crude analysis in lag 4 $(\mathrm{OR}=1.01495 \% \mathrm{CI} 1.001$ - 1.027), and exposure of pregnant women to ozone was associated with preterm delivery in the lag 1 of exposure, with $\mathrm{OR}=1.005$ (95\% CI 1.000 to 1.010); exposure to sulfur dioxide was not associated with preterm delivery in any form of analysis. Exposure to $\mathrm{PM}_{10}$, alone, was not statistically significant in the lags of seven, 15 and 30 days before delivery.

\subsubsection{Multipollutant model}

In the unadjusted analysis of all preterm infants, there was no evidence of an association between exposure to pollutants and preterm birth. In the adjusted analysis, i.e., that performed with newborns who fulfilled the inclusion criteria, only acute exposure to $\mathrm{PM}_{10}$ at lag 0 $(\mathrm{OR}=1.01195 \% \mathrm{CI} 1.001$ to 1.021$)$, lag $1(\mathrm{OR}=1.01395 \% \mathrm{CI} 1.003$ to 1.023$)$ and lag 3 $(\mathrm{OR}=1.01195 \%$ CI 1.001 to 1.022$)$ were statistically significant (Table 2). In the analysis of cumulative effects, ozone showed paradoxical protective behavior with exposure at 7 and 15 days before delivery.

Table 2. Odds Ratio coefficients (OR) and respective 95\% confidence intervals (95\% CI) to preterm birth according to air pollutants (lag 0 to lag 7), São José dos Campos, Brazil, 2005-2009.

\begin{tabular}{c|ccc}
\hline $\mathbf{L A G}$ & $\mathbf{S O}_{\mathbf{2}} \mathbf{O R}(\mathbf{9 5} \% \mathbf{C I})$ & $\mathbf{P M}_{\mathbf{1 0}} \mathbf{O R}(\mathbf{9 5 \%} \mathbf{C I})$ & $\mathbf{O}_{\mathbf{3}} \mathbf{O R}(\mathbf{9 5 \%} \mathbf{C I})$ \\
\hline $\mathbf{0}$ & $0.978(0.920-1.039)$ & $\mathbf{1 . 0 1 1}(\mathbf{1 . 0 0 1}-1.021) \#$ & $0.998(0.995-1.002)$ \\
$\mathbf{1}$ & $0.995(0.937-1.057)$ & $\mathbf{1 . 0 1 3}(\mathbf{1 . 0 0 3 - 1 . 0 2 3}) \#$ & $0.998(0.995-1.002)$ \\
$\mathbf{2}$ & $1.036(0.976-1.101)$ & $1.006(0.996-1.017)$ & $1.001(0.997-1.005)$ \\
$\mathbf{3}$ & $1.017(0.956-1.081)$ & $\mathbf{1 . 0 1 1}(\mathbf{1 . 0 0 1 - 1 . 0 2 2}) \#$ & $0.997(0.993-1.000)$ \\
$\mathbf{4}$ & $1.002(0.942-1.065)$ & $1.003(0.992-1.013)$ & $0.999(0.996-1.003)$ \\
$\mathbf{5}$ & $1.055(0.992-1.122)$ & $1.001(0.990-1.011)$ & $0.996(0.993-1.000)$ \\
$\mathbf{6}$ & $0.987(0.926-1.051)$ & $1.006(0.995-1.016)$ & $0.997(0.993-1.001)$ \\
$\mathbf{7}$ & $1.024(0.963-1.090)$ & $1.003(0.993-1.013)$ & $0.999(0.996-1.003)$ \\
\hline
\end{tabular}

$\# \mathrm{p}<0.05$.

Exposure to other pollutants was not associated with preterm delivery (Table 3). It was possible to estimate the chances of premature births in this time series by applying the results obtained by using logistic regression. When computed, the resulting mean value of this analysis for 0 lag was $33.6 \%(24.7 \%-54.4 \%)$, for the lag of 1 was $33.8 \%$ $(26.7 \%-59.7 \%)$ and for the lag of 3 was $35.5 \%$ (25.5\% - 58.0\%). The distribution of these chances has a seasonal aspect with greater chances occurring in the winter months (data not shown in figure). 
Table 3. Odds Ratio coefficients (OR) and respective 95\% confidence intervals (95\% CI) for preterm birth according to air pollutants (lags 7, 15 and 30 days - cumulative effects), São José dos Campos, Brazil, 2005-2009.

\begin{tabular}{c|ccc}
\hline $\mathbf{L A G}$ & $\mathbf{S O}_{2} \mathbf{O R}(\mathbf{9 5} \% \mathbf{C I})$ & $\mathbf{P M}_{\mathbf{1 0}} \mathbf{O R}(\mathbf{9 5} \% \mathbf{C I})$ & $\mathbf{O}_{\mathbf{3}} \mathbf{O R}(\mathbf{9 5} \% \mathbf{C I})$ \\
\hline $\mathbf{7}$ & $1.002(0.989-1.016)$ & $1.001(0.999-1.003)$ & $0.999(0.998-1.000) \#$ \\
$\mathbf{1 5}$ & $1.003(0.995-1.010)$ & $1.000(0.999-1.001)$ & $0.999(0.999-1.000) \#$ \\
$\mathbf{3 0}$ & $1.001(0.977-1.006)$ & $1.000(0.999-1.001)$ & $0.999(0.998-1.001)$ \\
\hline
\end{tabular}

$\# \mathrm{p}<0.05$

With an increase in the concentration of $\mathrm{PM}_{10}$ from 20 to $40 \mu \mathrm{g} \mathrm{m}-3$ and maintaining the concentrations of other pollutants, at the mean value of each one, the chance of occurrence of at least one premature birth increased from $30 \%$ to $38 \%$.

\section{DISCUSSION}

This study shows that exposure of pregnant women to $\mathrm{PM}_{10}$ was associated with preterm birth in the immediate days after these exposures, in a medium-sized city in southeastern Brazil. It is, to the best of our knowledge, the first study released in Brazil on the topic pollution and premature birth.

In the study site, the city of São José dos Campos, the prevalence of preterm delivery was $8.4 \%$, very close to that reported by Datasus for the state of São Paulo. Observing the distribution of preterm births according to the months in which they occurred, there seems to be a seasonal pattern when analyzed without the inclusion criteria; on the other hand, when these criteria were used, there seems to be no seasonal distribution. Perhaps the number of cases included, 769, was too small or the perhaps time series should include a larger number of years.

First, all preterm infants were analyzed, regardless of their preterm category, in unipollutant models. Isolated, exposure to $\mathrm{PM}_{10}$ showed statistically significant results, and was associated with preterm delivery when this exposure occurred four days before delivery, suggesting an acute effect of this exposure. The cumulative effects were not significant for this pollutant.

Exposure to $\mathrm{O}_{3}$ showed significant results only in the crude analysis. It was more important in the genesis of preterm infants when delivery came a day after exposure. $\mathrm{SO}_{2}$ was not statistically significant for all types of analysis.

When the pollutants were analyzed in a multipollutant model, in the crude analysis, without considering the inclusion criteria, it was not possible to identify an association between exposure and outcome. When the inclusion criteria was considered, only the $\mathrm{PM}_{10}$ was associated with preterm delivery in lags of 0,1 and 3; exposure to accumulated data of this pollutant was not associated with preterm birth. On the other hand, ozone presented a paradoxical behavior when the delivery occurred 7 and 15 days after exposure. Alves et al. (2010) reported this pattern, in a study on exposure to air pollutants and cardiorespiratory diseases.

Exposure to particulate matter has also been associated with premature newborn when maternal exposure occurred six weeks before delivery (Sagiv et al., 2005). To evaluate the role of exposure to $\mathrm{PM}_{10}$ and premature delivery, these authors used Poisson regression and, examining lags, the $\mathrm{PM}_{10}$ was significant in lags of 2 and 5 , results quite similar to the findings in our study. $\mathrm{Xu}$ et al. (1995) identified $\mathrm{SO}_{2}$ and TPS, being $\mathrm{PM}_{10}$ part of the TSP, as associated with the premature newborn at lags of $1,3,5$ and 7 , results very similar to those 
found in this study at São José dos Campos, citing that the mean values of $\mathrm{SO}_{2}$ were approximately 30 times higher than those found in the study presented here.

A study carried out in China (Zhao et al., 2011) showed the role of exposure to $\mathrm{PM}_{10}$ in premature births also in the 0 lag when this pollutant was analyzed together with the $\mathrm{SO}_{2}$ and $\mathrm{NO}_{2}$. In this Chinese study, the mean concentrations of $\mathrm{SO}_{2}$ and $\mathrm{PM}_{10}$ were $82.5 \mu \mathrm{g} \mathrm{m}^{-3}$ and $51.7 \mu \mathrm{g} \mathrm{m}^{-3}$ respectively, well above the values found in this Brazilian study.

It was also not possible to identify the association of prematurity with exposure to $\mathrm{SO}_{2}$. Probably the levels of this pollutant in São José dos Campos did not reach sufficient concentrations to cause adverse effects in pregnancy, since there are other studies that identified an association between the pollutant and preterm delivery (Zhao et al., 2011; Xu et al., 1995; Bobak, 2000).

Bobak (2000) concluded that the effects of pollutants were higher when the exposure occurred in the first trimester of pregnancy. Our study showed an acute effect of exposure to pollutants. The birth occurs the same day or no later than three days after exposure. These results indicate that there must be a mechanism for the effect of cumulative exposure and acute exposure. Possible causes would be cardiovascular mechanisms of oxidative stress, inflammation, coagulation and hemodynamic responses (Kannan et al., 2007).

Ritz et al. (2000) found an association with $\mathrm{PM}_{10}$ and $\mathrm{CO}$, when exposure occurred in the first quarter or in the end of pregnancy. These findings were confirmed in another study, also in California, with respect to $\mathrm{CO}$ and $\mathrm{PM}_{2.5}$ (Ritz et al., 2007). Maternal exposure in the third trimester of pregnancy was also associated with preterm delivery in Korea (Leem et al., 2006). Early and late exposures to $\mathrm{CO}$, total suspended particulates $\left(\mathrm{PM}_{10}, \mathrm{PM}_{2.5}\right), \mathrm{SO}_{2}$, and $\mathrm{NO}_{2}$ were significantly associated with the genesis of preterm birth in several papers (Sram et al., 2005; Lacasana et al., 2005; Wilhelm and Ritz, 2005; Huynh et al., 2006).

It should be noted that the association between air pollution and prematurity was found in polluted areas such as Los Angeles (Huynh et al., 2006) but also other areas with low levels of urban pollution (Bell et al., 2007).

Given the values of the concentrations of air pollutants in accordance with the air quality index, provided by Cetesb, and given the maximum values of the pollutants found in the present study, it is observed that $\mathrm{SO}_{2}$ always receives a rating of "good." The $\mathrm{PM}_{10}$ concentrations showed that the air quality became regular in $4.1 \%$ of days. The $\mathrm{O}_{3}$ concentrations showed that the air quality became regular in $44.8 \%$ and poor in $1.4 \%$ of days (Available at: http://sistemasinter.cetesb.sp.gov.br/Air/ar_indice_padroes.asp. Accessed on: April 10, 2012).

The aim of this study was not to identify which biological mechanism links exposure to air pollutants and preterm birth, but to present possible associations between exposure to air pollutants and preterm delivery. Although exposure to air pollutants has been identified as a risk factor for preterm birth, the biological mechanisms that lead to preterm birth and the critical period of vulnerability are not well understood; this critical period, or window as it is known, could be in early (first quarter) or late pregnancy (last quarter) as seen above (Bobak, 2000; Ritz et al., 2000;. Ritz et al., 2007; Leem et al., 2006).

Observing these results, several potential mechanisms can be considered. One possible explanation for the acute effect of air pollution on preterm birth suggests that air pollutants can generate inflammatory mediators in the lungs that influence the vascular circulatory function (Brook et al., 2003). Thus, inflammation has also been associated with premature birth and may be associated with inadequate placental perfusion (Knotternus et al., 1990; Zondervan et al., 1987)

In trying to understand the cumulative effects of pollutants, it can be speculated that chronic exposure to high levels of pollution can influence the functions of the placenta. The 
exposure to pollutants increases the viscosity of the blood and plasma fibrinogen, thereby decreasing the organ perfusion (Seaton et al., 1999).

Another explanation for the cumulative effects caused by exposure to pollutants during pregnancy points to maternal infections. Although air pollution does not directly cause infections, exposure to specific pollutants can impair immune function, which can increase susceptibility to infections (Hertz-Picciotto et al., 2002; Lee et al., 2011) and some infections are risk factors for preterm delivery (Silveira et al., 2008).

Possible limitations of the study are the analysis of three pollutants $\mathrm{O}_{3}, \mathrm{SO}_{2}$ and $\mathrm{PM}_{10}$, and not the impact of exposure to others pollutants such as $\mathrm{CO}$ and $\mathrm{NO}_{2}$, because the Cetesb measuring station does not quantify them. Another limitation could be that the data on air pollution were detected at a fixed monitoring site and, as such, do not represent accurately the level of individual exposure to pollutants, and so could underestimate the impact of pollution on health. Gestational age is difficult to measure accurately and so it may have been incorrectly estimated. Also, this information is not covered in detail, such as in weeks, for example. In the SINASC, the source of our data, this variable is presented as categorized. For this reason, it was not possible to perform analysis in quarters because there was no certainty in determining the true duration of pregnancy; it was therefore impossible to estimate the role of exposure to pollutants in early pregnancy.

Besides the above mentioned, it was not possible to obtain information on comorbidities, such as hypertension in pregnancy, noting that exposure to $\mathrm{PM}_{10}$ is associated with hospitalization for hypertension in medium-sized cities (Nascimento et al., 2012), because these data are not available on the website of Datasus nor is data on maternal habits, such as smoking.

It is also assumed that pregnant women moved freely around the city, constantly exposing themselves to pollutants, which disregards the fact that the pregnant woman is more sedentary at the end of pregnancy.

Despite the limitations of the work, it is noteworthy that the study covered a period of five years; during this period there were enough premature births to obtain a statistical result, minimizing potential fluctuations.

\section{CONCLUSIONS}

This work identified that maternal exposure to air pollutants, especially to particulate matter, can trigger premature births, which can occur both on the day that the mother was exposed to particulate matter and up to three days after the exposure. The importance of reducing premature birth is evident, as prematurity is responsible for much neonatal mortality and neonatal morbidity. The control of air pollution is among the measures that may be employed to bring about such a reduction.

\section{REFERENCES}

ALVES, C. A.; SCOTTO, M.; FREITAS, M. C. Air pollution and emergency admissions for cardiorespiratory diseases in Lisbon. Química Nova, v. 33, n 2, p. 337-344, 2010. http://dx.doi.org/10.1590/S0100-40422010000200020

BASCOM, R.; BROMBERG, P. A.; COSTA, D. A. et al. State of the art. Health effects Of outdoor pollution. American Journal of Respiratory and Critical Care Medicine, v. 153, n. 1, p. 3-50, 1996. 
BELL, M. L.; EBISU, K.; BELANGER, K. Ambient air pollution and low birth weight in Connecticut and Massachusetts. Environmental Health Perspectives, v. 115, p. 1118 - 1124, 2007. http://dx.doi.org/10.1289/ehp.9759

BOBAK, M. Outdoor air pollution, low birth weight, and prematurity. Environmental Health Perspectives, v. 108, p. 173-176, 2000.

BRAZIL. Ministry of Health. Departamento de Informática do SUS. Datasus. Available: http://tabnet.datasus.gov.br/cgi/tabcgi.exe?sinasc/cnv/nvuf.def. Access: May 102012.

BROOK, R. D.; BROOK, J. R.; URCH, B.; VINCENT, R.; RAJAGOPALAN, S. Inhalation much air pollution particles and ozone cause acute arterial vasoconstriction in healthy adults. Circulation, v. 105, p. 1534-1536, 2003.

HERTZ-PICCIOTTO I; DOSTÁL M; DEJMEK J; SELEVAN SG; WEGIENKA G; GOMEZ-CAMINERO A. et al. Air pollution and distributions of lymphocyte immunophenotypes in cord and maternal blood at delivery. Epidemiology, v. 13, n.2, p.172-183, 2002.

HUYNH, M.; WOODRUFF, T. J.; PARKER, J. D.; SCHOENDORF, K. C. Relationships between air pollution and preterm birth in California. Paediatric and Perinatatal Epidemiology, v. 20, p. 454-461, 2006. http://dx.doi.org/10.1111/j.1365-3016.2006. 00759.x

KANNAN, S.; MISRA, D. P.; DVONCH, J. T.; KRISHNAKUMAR, A. Exposures to airborne particulate matter and adverse perinatal outcomes: a biological plausible mechanistic framework for exploring potential. Ciência \& Saúde Coletiva, v. 12, n. 6, 2007. http://dx.doi.org/10.1590/S1413-81232007000600020

KNOTTERNUS, J. A.; DELGADO, L. R.; KNIPSCHILD, P. G.; ESSED, G. G.; SMITS, F. Haematological parameters and pregnancy. A prospective study in the third quarter. Journal of Clinical Epidemiology, v. 43, p. 461-466, 1990.

LACASANA, M.; ESPLUGUES, A.; BALLESTER, F. Exposure to ambient air pollution and health effects on prenatal and early childhood. European Journal of Epidemiology, v. 20,p p. 183 - 199, 2005. http://dx.doi.org/10.1007/s10654-004-3005-9

LEE, P. C.; TALBOT, E. O.; ROBERTS, J. M.; CATOV, J. M.; SHARMA, R. K.; RITZ, B. Particulate air pollution exposure and C-reactive Protein during early pregnancy. Epidemiology, v. 22, p. 524-531, 2011. http://dx.doi.org/10.1097/EDE.0b013e31821c6c58

LEEM, J. H.; KAPLAN, B. M.; SHIM, Y. K.; POHL, H. R.; GOTWAY, C. A.; BULLARD, S. M. et al. Exposures to air Pollutants during pregnancy and preterm delivery. Environmental Health Perspectives, v. 114, n. 6, p. 905-910, 2006. http://dx.doi.org/10.1289/ehp.8733

NASCIMENTO, L. F. C. Epidemiology of preterm deliveries in Southeast Brasil: a hospitalbased study. Revista brasileira de Saúde materno infantil, v. 1, p. 263-268, 2001. http://dx.doi.org/10.1590/S1519-38292001000300007

NASCIMENTO, L. F. C.; FRANCISCO, J. B.; PATTO, M. B. R.; ANTUNES, A. M. Particulate matter and hospital admission due to arterial hypertension in a Brazilian medium-size city. Cadernos de Saúde Pública, v. 28, n. 7, p. 1319-1324, 2012. http://dx.doi.org/10.1590/S0102-311X2012000700010 
NASCIMENTO, L. F. C.; MOREIRA, D. A. Are environmental pollutants risk factors for low birth weight? Cadernos de Saúde Pública, v. 25, n 8, p. 1791-1796, 2009. http://dx.doi.org/10.1590/S0102-311X2009000800015

RITZ, B.; WILHELM, M.; HOGGATT, K. J.; GHOSH, J. K. C. Ambient air pollution and preterm birth in the UCLA environment and pregnancy outcomes study at the University of California, Los Angeles. American Journal of Epidemiology, v. 166, n. 9, p. 1045-1052, 2007. http://dx.doi.org/10.1093/aje/kwm181

RITZ, B.; YU, F.; CHAPA, G.; FRUIN, S. Effect of air pollution on preterm birth among children born in Southern California between 1989 and 1993. Epidemiology, v. 11, p. 502-511, 2000.

SAGIV, S. K.; MENDOLA, P.; LOOMIS, D.; HERRING, A. H.; NEAS, L. M.; SAVITZ, D. A. et al. A time series analysis of air pollution and preterm birth in Pennsylvania, 1997-2001. Environmental Health Perspectives, v. 113, n. 5, p. 602-606, 2005. http://dx.doi.org/10.1289/ehp.7646

SEATON, A.; SOUTAR, A.; CRAWFORD, V.; ELTON, R.; MCNERLAN, S.; CHERRIE, J. et al. Particulate air pollution and the blood. Thorax, v. 54, n.11, p. 1027- 1032, 1999. http://dx.doi.org/10.1136/thx.54.11.1027

SILVEIRA, M. F.; SANTOS, I. S.; BARROS, A. J. D.; MATIJASEVICH, A.; BARROS, F. C.; VICTORA, C. G. Increase in preterm births in Brazil: review of population-based studies. Revista de Saúde Pública, v. 42, n. 5, p. 957-964, 2008. http://dx.doi.org/10.1590/S0034-89102008000500023

SRAM, R. J.; BINKOVA, B.; DEJMEK, J.; BOBAK, M. Ambient air pollution and pregnancy outcomes: a literature review. Environmental Health Perspectives, v. 113, p. 375 - 382, 2005. http://dx.doi.org/10.1289/ehp.6362

STEB, D. M.; CHEN, L.; ESHOUL, M.; JUDEK, S. Ambiente air pollution, birth weight and preterm birth: a systematic review and meta-analysis. Environmental Research, v. 117, p. 100 - 101, 2012. http://dx.doi.org/10.1016/j.envres.2012.05.007

TUCKER, J.; MCGUIRE, W. Epidemiology of preterm birth. British Medical Journal, v. 329, p. 675-678, 2005.

VAAST, P.; HOUFFLIN-DEBARGE, V.; DERUELLE, P.; SUBTIL, D.; STORNE, L.; PUECH, F. Could the consequences of premature delivery be futher attenuated by means of new prenatal strategies? European Journal Of Obstetrics Gynecology and Reproductive Biology, v. 117, Suppl 1, p. p. 21-24, 2004. http://dx.doi.org/10.1016/j.ejogrb.2004.07.013

WORLD HEALTH ORGANIZATION. International statistical classification of diseases and related health problems. $10^{\text {th }}$ Revision. Geneva, 1993.

XU, X.; DING, H.; WANG, X. Acute effects of total suspended particles and sulfur dioxides on preterm delivery: a community-based cohort study. Archives of Environmental Health and Perspectives, v. 50, n. 6, p. 407-415, 1995. 10.1080/00039896.1995.9935976

WILHELM, M.; RITZ, B. Local variations in CO and particulate air pollution and adverse birth outcomes in Los Angeles, California, USA. Environmental Health Perspectives, v. 113, p. $1212-1221,2005$. http://dx.doi.org/10.1289/ehp.7751 
ZHAO, Q.; LIANG Z.; TAO, S.; ZHU, J.; DU, Y. Effects of air pollution on neonatal prematurity in Guangzhou of China: a time-series study. Environmental Health, v. 10, p. 2, 2011. http://dx.doi.org/10.1186/1476-069X-10-2

ZONDERVAN, H. A.; OOSTING, J.; HARDEMAN, M. R.; SMORENBERG-SCHOORL, M. E.; TREFFERS, P. E. The influence of maternal whole blood viscosity in fetal growth. European Journal Of Obstetrics Gynecology And Reproductive Biology, v. 25, p. 187-194, 1987. http://dx.doi.org/10.1016/0028-2243(87)90098-0 